\title{
PENGARUH MOBILISASI DINI TERHADAP SUARA PERISTALTIK USUS PADA PASIEN POST OP APPENDECTOMY DI RUMAH SAKIT UMUM ROYAL PRIMA MEDAN
}

\author{
Nora Santika ${ }^{1}$, Wiwik Listari ${ }^{2}$, Nur Ainun ${ }^{3}$, Lela Rahmadani ${ }^{4}$ \\ Patimah Sari siregar ${ }^{5}$ \\ 1,2,3,4 Mahasiswa Fakultas Keperawatan dan Kebidanan UNPRI, \\ Email : wiwik.dalimunthe97@gmail.com \\ ${ }^{5}$ Dosen Fakultas Keperawatan dan Kebidanan UNPRI \\ Email : patimahsari818@gmail.com
}

\section{ABSTRACT : THE EFFECT OF EARLY MOBILIZATION ON INTESTINAL PERISTALSIS IN POST-OP APPENDECTOMY PATIENTS AT THE ROYAL PRIMA MEDAN HOSPITAL}

Backgroud : Surgery is done by taking certain parts of the body, with the aim of repairing the body that has abnormalities such as Appendectom. This action can disable the peristaltic sound with the anesthetized body. Early mobilization is one of the effective ways to re-stimulate intestinal function and produce normal peristalsis, and the patient can recover

Purpose : This study aims to determine the effect of early mobilization on peristaltic sounds of usu in post op Appendectom patients. This research method is quasy experiment with one group pre test post test design, the sample in this study amounted to 25 people.

Methods : Of collecting data uses accidental sampling. Retrieval of data using observation sheets.

Results : Of the study using paired t-test can be seen from Sig. (2-tailed) 0,000 $<0.05$.

Conclusion: Is that early mobilization has an influence on intestinal peristalytic sounds in post op appendectomy patients at the Royal Prima General Hospital Medan.

Keywords: appendectomy, early mobilization, intestinal peristaltic

INTASARI : PENGARUH MOBILISASI DINI TERHADAP SUARA PERISTALTIK USUS PADA PASIEN POST OP APPENDECTOMY DI RUMAH SAKIT UMUM ROYAL PRIMA MEDAN

Pendahuluan : Pembedahan dilakukan dengan cara mengambil bagian tubuh tertentu, dengan tujuan perbaikan tubuh yang mengalami kelainan seperti tindakan Appendectomy. Tindakan ini dapat menonaktifkan suara peristaltic dengan keadaan tubuh yang dibius. Mobilisasi dini salah satu jalan efektif dalam merangsang kembali fungsi usus dan menghasilkan suara peristaltik normal, dan pasien dapat pulih.

Tujuan : Penelitian bertujuan untuk mengetahui pengaruh mobilisasi dini terhadap suara peristaltic usu pada pasien post op Appendectomy.

Nora Santika ${ }^{1}$, Wiwik Listari ${ }^{2}$, Nur Ainun ${ }^{3}$, Lela Rahmadani ${ }^{4}$,Patimah Sari siregar ${ }^{5}$

1,2,3,4 Mahasiswa Fakultas Keperawatan dan Kebidanan UNPRI. Email :

wiwik.dalimunthe97@gmail.com

${ }^{5}$ Dosen Fakultas Keperawatan dan Kebidanan UNPRI. Email : patimahsari818@gmail.com 
Metode : Penelitian menggunakan metode quasy experiment dan desain penelitian one grup pre test post test, sampel dalam penelitian ini berjumlah 25 orang. Metode pengambilan data menggunakan Accidental sampling. Pengambilan data menggunakan lembar observasi.

Hasil penelitian : Menggunakan uji paired t- test dapat dilihat dari Sig. (2tailed) $0,000<0,05$.

Kesimpulan :Bahwa mobilsasi dini memiliki pengaruh terhadap suara peristalitik usus pada pasien post op appendectomy di Rumah Sakit Umum Royal Prima Medan.

Kata kunci : Appendectomy, Mobilisasi dini, Peristaltic usus

\section{PENDAHULUAN}

Tindakan Operasi termasuk dalam metode penyembuhan penyakit yang merupakan kategori pengobatan yang tidak bisa dilakukan dengan cara tradisional. Pembedahan dilakukan dengan cara mengambil bagian tubuh tertentu, dengan tujuan perbaikan tubuh yang mengalami kelainan. Tindakan Operasi dilakukan karena berbagai alasan, salah satunya tindakan Appendectomy. Appendectomy merupakan pengambilan jaringan atau organ dalam tubuh yang mengalami peradangan. Peradangan usus buntu ( Appendicitis) dapat disebabkan oleh tersumbatnya usus buntu karena adanya tinja atau membengkaknya kelenjar getah bening dalam dinding usus (Wira, 2016).

$\begin{array}{lcr}\begin{array}{c}\text { Menurut } \\ \text { Organization }\end{array} & \begin{array}{c}\text { World } \\ \text { (WHO, }\end{array} & \begin{array}{r}\text { Health } \\ \text { 2016) }\end{array} \\ \text { menunjukan } & \text { bahwa } & \text { insiden } \\ \text { Appendectomy sekitar } & 4,8 \% \text { dan } \\ 2,6 \% \text { sebagai } & \text { total } & \text { populasi }\end{array}$ penduduk Asia dan Afrika yang menderita apendisitis. Di Amerika sekitar $7 \%$ penduduk menjalani apendiktomi dengan insidens 11 /10.000 populasi pertahun. Menurut hasil tersebut laki-laki lebih beresiko apendisitis dibanding wanita dengan resio 1,4:1. Banyaknya pergerakan aktifitas pada laki- laki , tinja lebih mudah untuk masuk kedalam usus buntu dan menyumbat.

Banyak faktor penyebab terjadinya appendicitis salah satunya adalah makanan yang mengandung zat racun sehingga kinerja tubuh terganggu dalam mencerna. Di Indonesia kejadian appendicitis sebesar 95 per 1000 penduduk, terkena kasus ini mencapai 10 juta setiap tahunnya, sebagai angka kasus tertinggi di ASEAN. Dari hasil tersebut Beragam makanan yang dikonsumsi mulai dari yang instan, gorengan, makanan yang dibakar langsung, makanan asin dan pedas (Widarsa, 2017).

Suara Peristaltik mengandung aliran udara dan cairan yang dapat membentuk gerakan peristaltic seperti suara gemuruh pelan yang terjadi secara tidak teratur Apabila kinerja otot- otot usus terganggu maka akan terjadi ketidakefektipan dalam mendorong isi usus kebawah, efek dari itu mengakibatkan terganggunya peristaltic dan mengakibatkan konstipasi dan dapat beresiko terjadinya komplikasi lain seperti ileus (Potter \& Perry, 2015).

Kejadian Appendectomy di Sumatera terlihat tinggi. Angka penyakit appendectomy lebih tinggi di Negara maju. karena disebakan kurangnya serat serta tingginya

Nora Santika ${ }^{1}$, Wiwik Listari ${ }^{2}$, Nur Ainun ${ }^{3}$, Lela Rahmadani ${ }^{4}$, Patimah Sari siregar $^{5}$

1,2,3,4 Mahasiswa Fakultas Keperawatan dan Kebidanan UNPRI. Email :

wiwik.dalimunthe97@gmail.com

${ }^{5}$ Dosen Fakultas Keperawatan dan Kebidanan UNPRI. Email : patimahsari818@gmail.com 
asupan gula dan lemak yang dikonsumsi penduduk di Negara industri tersebut. Lemak berlebih sangat berpengaruh dalam tubuh terutama asupan nutrisi ke otot terganggu.

Kelemahan tonus otot rangka dapat memberikan efek melemahnya proses pembuangan zat sisa dalam tubuh. Salah satu tindakan yang dapat merangsang kembalinya saraf otot dalam bekerja adalah dengan melakukan gerakan - gerakan yang dapat meningkatkan kemampuan seseorang untuk mendorong terjadinya kontraksi pada organ dalam perut disebut juga mobilisasi (Kozier, 2016).

Mobilisasi merupakan

tindakan yang dilakukan seseorang secara bebas. Dilakukan dengan gerakan - gerakan tertentu dan mempunyai tujuan untuk mendorong kemandirian. Gerakan juga dapat mempengaruhi penyembuhan luka (Mubarak, 2015).

Berdasarkan hasil penelitian yang diperoleh oleh (Anggraini, 2015) mengatakan pasien yang sulit melakukan mobilisasi setelah operasi dapat memperlambat proses penyembuhan luka dan kemungkinan akan berpotensi timbulnya komplikasi pasca bedah seperti Pneumonia dan Peritonitis atau Abses. Berdasarkan hasil survey pendahuluan yang dilakukan di Rs Royal Prima Medan diambil dari data Rekam Medis, jumlah pasien yang melakukan tindakan operasi Appendectomy pada tahun 2019 mulai bulan Maret sampai Oktober berjumlah 166 kasus. Hasil wawancara awal yang dilakukan peneliti kepada seorang pasien terdiagnosa Appendectomy di RS Royal Prima Medan, pasien mengatakan belum mengerti manfaat dari mobilisasi fisik, sehingga sangat sedikit yang melakukan mobilisasi fisik. Karena selama ini pasien hanya dianjurkan agar melakukan gerakan-gerakan tertentu tanpa ada pantauan. Di hari pertama sampai hari kedua Pasca bedah Appendectomy pasien masih takut melakukan gerakan dan hanya tirah baring sehingga membuat pasien lemas dan fokus pada luka bedah. Hari ketiga pasien mulai melakukan gerakan miring kiri dan kanan, dan tidak sedikit pasien yang mengeluh nyeri .

\section{METODE PENELITIAN}

Jenis penelitian kuantatif
dengan menggunakan Quasy
Experiment serta desain satu
kelompok One group pre-test post-
test untuk mengetahui pengaruh
mobilisasi dini terhadap suara bising
usus pada pasien post appendectomy
Rumah Sakit Royal Prima Medan
seluruh pasien Post Appendectomy di Rumah Sakit Royal Prima Medan sebanyak 166 orang. Sampel dalam penelitian menggunakan rumus Arikunto (2016), dimana jika populasi > 100 maka peneliti bisa membuat jumlah sampel (10\%-15\% dan 20\%-25\%) dari jumlah populasi. Peneliti mengambil 15\% dari jumlah populasi. Berdasarkan rumus diatas sampel ini diambil dalam penelitian 25 orang,serta teknik pengambilan sampel menggunakan Accidental Sampling yaitu pengambilan sampel yang secara kebetulan ditemui saat itu.

Instrumen dalam penelitian ini menggunakan alat stetoskop, tensi meter temperetur, kuesioner dan lembar obseravasi dengan Aspek pengukuran terdiri dari tahap pretest dan post test.

Nora Santika ${ }^{1}$, Wiwik Listari ${ }^{2}$, Nur Ainun ${ }^{3}$, Lela Rahmadani ${ }^{4}$ Patimah Sari siregar $^{5}$

1,2,3,4 Mahasiswa Fakultas Keperawatan dan Kebidanan UNPRI. Email :

wiwik.dalimunthe97@gmail.com

${ }^{5}$ Dosen Fakultas Keperawatan dan Kebidanan UNPRI. Email : patimahsari818@gmail.com 
Lembar kuesioner dan lembar observasi terdiri dari informed consent, biodata (Umur, jenis kelamin, pekerjaan). lembar kuesioner terdiri dari 10 pertanyaan dimana dari 10 pertanyaan tersebut dibagi 3 aspek pengukuran yaitu sangat mampu benar menjawab 8-10 pertanyaan, mampu benar menjawab 5-7 pertanyaan dan tidak mampu benar menjawab 0-4 pertanyaan.

Penelitian dimulai dengan mengirimkan surat izin awal penelitian dan mengambil data survei awal, sebelum dilakukan penelitian terlebih dahulu melakukan uji etik dengan nomor 036/KEPK/UNPRI/V/2020 selanjut nya baru dilakukan penelitian.

Sebelum proses penelitian dilakukan terlebih dahulu informed consent dan mengisi biodata responden dan melakukan pengecekan peristaltik usus setelah 6-8 jam post op dengan menggunkan stetoskop pada pasien post appendectomy. Selanjutnya responden diarahkan untuk mengisi lembar kuesioner pre-test yang telah disediakan. Proses tindakan dimulai dari mengatur posisi responden, mengukur vital sign, menganjurkan mengangkat alat gerak atas tangan kanan dan kiri serta alat gerak bawah tekuk-tekuk kaki selama 1530 menit, setelah 12-24 jam post op menganjurkan miring kanan miring kiri, hari ke 2-3 post op menganjurkan duduk secara perlahan-lahan hinggan hari ke 4 menganjurkan berdiri dan berjalan kekamar mandi tanpa bantuan. Dan selanjutnya melakukan post-test pengecekan kembali peristaltik usus. Setelah hasil data penelitian didapat dan diolah menggunakan SPSS 16.0.

HASIL

Tabel 1 Distribusi Frekuensi Karakterisik Responden Berdasarkan Umur pada Pasien Post Op Appendectomy di Rumah Sakit Umum Royal Prima Medan

\begin{tabular}{ccc}
\hline Umur & Frekuensi $(\mathrm{F})$ & Persentase $(\%)$ \\
\hline 20-29 Tahun & 16 & 64 \\
30-39 Tahun & 6 & 24 \\
40-49 Tahun & 2 & 8 \\
$>5$ Tahun & 1 & 4 \\
\hline Total & 25 & 100 \\
\hline
\end{tabular}

Berdasarkan tabel 1 diatas dapat dilihat bahwa responden brdasarkan jenis kelamin pada umur 20-29 tahun sebanyak 16 orang (64 \%), dan minoritas

responden terdapat pada umur $>50$ tahun sebanyak 1 orang (4\%).

Tabel 2 Distribusi Frekuensi Karakterisik Responden Berdasarkan Jenis Kelamin pada Pasien Post Op Appendectomy di Rumah Sakit Umum Royal Prima Medan

\begin{tabular}{ccc}
\hline Jenis Kelamin & Frekuensi $(\mathrm{F})$ & Persentase $(\%)$ \\
\hline Laki-laki & 11 & 44 \\
Perempuan & 14 & 56 \\
\hline Total & 25 & 100
\end{tabular}

Nora Santika ${ }^{1}$, Wiwik Listari ${ }^{2}$, Nur Ainun ${ }^{3}$, Lela Rahmadani ${ }^{4}$,Patimah Sari siregar $^{5}$ 1,2,3,4 Mahasiswa Fakultas Keperawatan dan Kebidanan UNPRI. Email : wiwik.dalimunthe97@gmail.com

${ }^{5}$ Dosen Fakultas Keperawatan dan Kebidanan UNPRI. Email : patimahsari818@gmail.com 
Berdasarkan tabel 2 diatas dapat dilihat bahwa mayoritas responden berjenis kelamin perempuan sebanyak 14 orang (56 \%), dan minoritas responden berjenis kelamin laki- laki sebanyak 11 orang ( $44 \%)$.

Tabel 3 Distribusi Frekuensi Karakterisik Responden Berdasarkan Pekerjaan pada Pasien Post Op Appendectomy di Rumah Sakit Umum Royal Prima Medan

\begin{tabular}{ccc}
\hline Pekerjaan & Frekuensi $(\mathrm{F})$ & Persentase $(\%)$ \\
\hline IRT & 8 & 32 \\
PNS & 4 & 16 \\
Pelajar & 4 & 16 \\
Wirswasta & 9 & 36 \\
\hline Total & 25 & 100 \\
\hline
\end{tabular}

Berdasarkan tabel 3 diatas dapat dilihat bahwa responden berdasarkan pekerjaan mayoritas wiraswasta sebanyak 9 orang (36.\%), dan minoritas responden sebagai PNS dan Pelajar sebanyak 4 orang $(16 \%)$.

Tabel 4 Distribusi Frekuensi Sebelum Dilakukan Mobilisasi Dini Terhadap Suara Peristaltik Usus Pada Pasien Post Op Appendectomy di Rumah Sakit Umum Royal Prima Medan

\begin{tabular}{ccc}
\hline Suara Peristaltik Usus & Frekuensi $(\mathrm{F})$ & Persentase $(\%)$ \\
\hline Positif & 4 & 16 \\
Negarif & 21 & 84 \\
\hline Total & 25 & 100 \\
\hline Berdasarkan tabel 4 diatas dapat & appendectomy yang positif sebanyak \\
dilihat bahwa suara peristaltik usus & 4 orang (16\%), sedangkan yang \\
sebelum dilakukan tindakan & negatif sebanyak 21 orang (84 \%).
\end{tabular}

mobilisasi dini pada pasien post op

Tabel 5 Distribusi Frekuensi Mobilisasi Dini Terhadap Suara Peristaltik Usus Pada Pasien Post Op Appendectomy di Rumah Sakit Umum Royal Prima Medan

\begin{tabular}{ccc}
\hline Mobilisasi Dini & Frekuensi $(\mathrm{F})$ & Persentase $(\%)$ \\
\hline Sangat Mampu & 9 & 36 \\
Mampu & 13 & 52 \\
Tidak Mampu & 3 & 12 \\
\hline Total & 25 & 100 \\
\hline
\end{tabular}

Berdasarkan tabel 5 diatas dapat dilihat bahwa mayoritas responden mampu melakukan mobilisasi dini sebanyak 13 orang $(52 \%)$, sedangkan minoritas tidak mampu melakukan mobilsasi dini sebanyak 3 orang $(12 \%)$.

Nora Santika ${ }^{1}$, Wiwik Listari ${ }^{2}$, Nur Ainun ${ }^{3}$, Lela Rahmadani ${ }^{4}$ Patimah Sari siregar $^{5}$

1,2,3,4 Mahasiswa Fakultas Keperawatan dan Kebidanan UNPRI. Email :

wiwik.dalimunthe97@gmail.com

${ }^{5}$ Dosen Fakultas Keperawatan dan Kebidanan UNPRI. Email : patimahsari818@gmail.com 
Tabel 6 Distribusi Frekuensi Sesudah Dilakukan Mobilisasi Dini Terhadap Suara Peristaltik Usus Pada Pasien Post Op Appendectomy di Rumah Sakit Umum Royal Prima Medan

\begin{tabular}{ccc}
\hline Suara Peristaltik Usus & Frekuensi $(\mathrm{F})$ & Persentase $(\%)$ \\
\hline Positif & 18 & 72 \\
Negarif & 7 & 28 \\
\hline Total & 25 & 100 \\
\hline
\end{tabular}

Berdasarkan tabel 6 diatas dapat dilihat bahwa suara peristaltik usus sesudah dilakukan tindakan mobilisasi dini pada pasien post opappendectomy yang positif suara peristaltik sebanyak 18 orang $(72 \%)$, sedangkan yang negatif sebanyak 7 orang $(28 \%)$

Tabel 7 Distribusi Frekuensi Pengaruh Mobilisasi Dini Terhadap Suara Peristaltik Usus Pada Pasien Post Op Appendectomy di Rumah Sakit Umum Royal Prima Medan Tahun 2020.

\begin{tabular}{cccccccc}
\hline & \multicolumn{9}{c}{ Suara Peristaltik Usus } & \multirow{2}{*}{$\begin{array}{c}P \\
\text { Mobilisasi Dini }\end{array}$} & \multicolumn{2}{c}{ Positif } & \multicolumn{2}{c}{ Negatif } & \multicolumn{2}{c}{ Total } & Value \\
\cline { 2 - 7 } & $\mathrm{F}$ & $\%$ & $\mathrm{~F}$ & $\%$ & $\mathrm{f}$ & $\%$ & \\
Sangat Mampu & 9 & 36 & - & - & 9 & 36 & \\
Mampu & 9 & 36 & 4 & 16 & 13 & 52 & 0.004 \\
Tidak Mampu & - & - & 3 & 12 & 3 & 12 & \\
\hline Total & 18 & 72 & 7 & 28 & 25 & 100 & \\
\hline
\end{tabular}

Berdasarkan tabel 7 diatas dapat dilihat bahwa yang sangat mampu melakukan mobilisasi dini dengan suara peristalitik positif sebanyak 9 orang (36\%), dan yang mampu melakukan mobilsasi dini suara peristaltik usus 9 orang (36\%) sedangkan tidak mampu melakukan mobilsasi dini dengan suara peristaltik usus positif tidak ada.

Tabel 8 Distribusi Frekuensi nilai rata-rata pretest dan postest suara peristaltik usus pada pasien post op appendectomy di Rumah Sakit Umum Royal Prima Medan.

\begin{tabular}{ccccc}
\hline Suara Peristaltik Usus & $\mathrm{F}$ & Mean & Std. Deviation & $\begin{array}{c}\text { Sig. (2- } \\
\text { tailed) }\end{array}$ \\
\hline Pretest & 25 & 1,84 & 0,374 & 0,000 \\
Postest & 25 & 1,28 & 0,458 & 0,000 \\
\hline
\end{tabular}

Berdasarkan tabel 8 dapat dijelaskan bahwa suara peristataltik usus sebelum dan sesudah dilakukan mobilsasi dini hasilnya mempunyai perubahan dapat dilihat Sig. (2tailed) $\quad 0,000<0,05$ maka bisa diartikan bahwa mobilsasi dini memiliki pengaruh terhadap suara peristalitik usus.

Nora Santika ${ }^{1}$, Wiwik Listari ${ }^{2}$, Nur Ainun ${ }^{3}$, Lela Rahmadani ${ }^{4}$ Patimah Sari siregar $^{5}$

1,2,3,4 Mahasiswa Fakultas Keperawatan dan Kebidanan UNPRI. Email :

wiwik.dalimunthe97@gmail.com

${ }^{5}$ Dosen Fakultas Keperawatan dan Kebidanan UNPRI. Email : patimahsari818@gmail.com 


\section{PEMBAHASAN}

\section{Karakteristik Responden a. Umur}

Dilihat dari hasil penelitian bahwa, responden pada rentan usia 20-29 tahun. Responden mengatakan bahwa mereka tidak terlalu mengutamakan pola hidup sehat sehingga kurang mengonsumsi makanan yang tinggi serat yaitu sayuran dan buah-buahan. Makanan jenis cepat saji juga sering dikonsumsi bahkan mengolah makanan tersebut dengan cara yang tidak sehat dan hygenis. Dalam penelitian ini didapatkan juga dari hasil pengumpulan data yang dilakukan bahwa, kurangnya pengetahuan responden tentang mobilisasi sehingga takut dalam melakukan gerakan- gerakan mobilisasi, salah satu ketakutan responden dalam melakukan gerakan yaitu lepasna jahitan luka pada bekas operasi. Edukasi yang dilakukan peneliti mampu membantu pasien dalam meningkatkan percaya diri dalam melakukan mobilisasi dini. Gerakan yang dilakukan oleh responden sangat merangsang peristaltic untuk berfungsi kembali setelah beberapa jam non aktif.

Semakin tua usia, maka akan semakin rentan seseorang dalam mengalami masalah pemulihan peristaltik usus post operasi. Karena dapat dilihat secara fisiologis, usia dewasa hingga lanjut usia dapat mengalami penurunan fungsi alat tubuh khususnya pada bagian pencernaan. Hal tersebut akan mengakibatkan pengurangan tonus otot yang normal di otot - otot polos kolon, sehingga peristaltik usus akan melemah dan melambat.

\section{b. Jenis kelamin}

Dari hasil wawancara yang dilakukan peneliti bahwa responden menyatakan, mayoritas responden berjenis kelamin perempuan kurang aktif dalam mempertahankan kebiasaan hidup sehat. Hidup yang tidak sehat yang sering dilakukan sehari-hari salah satunya seperti jadwal makan yang tidak teratur, kurangnya istirahat atau tidur tidak teratur, kurangnya dalam mengonsumsi air putih serta adanya pengaruh hormon.

Hormon yang terdapat pada perempuan adalah estrogen dan progesterone. Kinerja hormon dapat mempengaruhi system organ dalam termasuk dalam penurunan dan peningkatan peristaltic usus. Hormon juga berperan penting dalam merelaksasi otot- otot polos (Mark \& Liebermen, 2012).

Dalam peneliti sebelumnya yang dilakukan oleh Suratun dan Sasmita 2019, bahwa mayoritas yang berjenis kelamin perempuan 21 orang dari 36 orang lebih sensitive terhadap rangsangan nyeri. Hal tersebut mendorong responden dalam melakukan mobilisasi, sehingga lebih cepat melakukan mobilisasi dini dengan bantuan.

\section{c. Pekerjaan}

Setelah dilakukan penelitian, hasil komunikasi yang dilakukan oleh peneliti dengan subyek bahwa reponden yang berprofesi sebagai wiraswasta kurang mengetahui mobilisasi, reponden menyatakan bahwasanya sering mengonsumsi makanan tanpa memperhatikan kebersihan makanan yang dikonsumsi, bahkan mereka lebih mengutamakan pekerjaan sehingga kurang dalam memperhatikan

Nora Santika ${ }^{1}$, Wiwik Listari ${ }^{2}$, Nur Ainun ${ }^{3}$, Lela Rahmadani ${ }^{4}$ Patimah Sari siregar $^{5}$

1,2,3,4 Mahasiswa Fakultas Keperawatan dan Kebidanan UNPRI. Email :

wiwik.dalimunthe97@gmail.com

${ }^{5}$ Dosen Fakultas Keperawatan dan Kebidanan UNPRI. Email : patimahsari818@gmail.com 
kesehatan. Disamping kebutuhan yang semakin mahal serta tanggung jawab dengan keluarga.

Menurut Notoadmodjo 2012 pekerjaan sangat mempengaruhi pengetahuan dan akan melakukan apa yang diketahuinya. Dalam hal ini asumsi peneliti berkesanjungan dengan hasil penelitian bahwa responden yang berprofesi sebagai wiraswasta kurang dalam mengetahui tentang appendectomy sehingga kurang aktif dalam melakukan mobilisasi. Informasi peneliti sangat dibutuhkan oleh responden untuk kemandirian responden.

\section{Analisa Univariat}

Hasil penelitian diatas mayoritas responden sangat mampu melakukan gerakan mobilisasi dini. Edukasi sangat membantu subyek dalam melakukan gerakan- gerakan mobilisasi. Dalam hal ini instruksi peneliti serta dukungan keluarga menjadi motivasi bagi responden. Mobilisasi merupakan cara yang sangat efektif dalam mengaktifkan fungsi peristaltic. Salah satunya dimulai dari gerakan miring kiri dan miring kanan secara perlahan, kemudian dilanjut pada gerakan duduk dengan bantuan sampai dengan mampu melakukan mobilisasi jalan dengan mandiri. Suara peristaltic pada hari pertama post operasi belum terdengar (hipo). Kondisi ini membuat pasien kwatir dan merasakan kebas serta mual dan muntah. Efek anastesi mampu menonaktifkan suara peristaltic selama 6- 12 jam, sehingga mengakibatkan pasien lemah bahkan butuh asupan oksigen yang cukup.

\section{Analisa Bivariat .}

Gerakan yang dilakukan responden terdiri dari dua tahap, mulai dari belajar menggerakkan badan kearah kanan dan kiri, posisi duduk, sampai dengan belajar berjalan tanpa bantuan. Gerakan tersebut dilakukan dengan instruksi dan edukasi peneliti dan setelah selesai peneliti mengecek suara peristaltic usus responden. Bahwa mobilisasi dini memiliki pengaruh terhadap suara peristaltik usus pada pasien pasca Operasi Appendectomy dengan nilai sig. (2- tailed) 0,000

$$
\text { Penelitian ini memiliki }
$$

kesamaan dengan penelitian Srihayanti, dkk (2016) menujukkan nilai signifikasi 0,000 hal tersebut membuktikan bahwa terdapat mobilisasi Range of Motion Pasif terdapat pemulihan peristaltik usus pada pasien post pembedahan. Melakukan pembedahan dengan anestesi regional, sebaliknya penelitian terkait melakukan penelitian pada pasien post pembedahan dengan anestesi umum. Basri dan Nanuk (2018) mengatakan bahwa peristaltik usus yaitu suara gemiricing diperoleh dari suatu kontraksi ritmik dan gerakan mendorong suatu proses pencampuran makanan di secara oral sehingga proses penyembuhan luka post pemebedahan pun terhambat. Supaya dapat memperoleh proses pemulihan peristaltik usus pasien post pembedahan lebih cepat maka perlu dilakukannya mobilsasi dini setelah bebeberapa jam post operasi. Hasil peneliti sebelumnya oleh Mario e, dkk (2018). Menggunakan metode penelitian accidental sampling dengan menggunakan uji Man Whitney diperoleh nilai $p 0,000<0,05$.

Nora Santika ${ }^{1}$, Wiwik Listari ${ }^{2}$, Nur Ainun ${ }^{3}$, Lela Rahmadani ${ }^{4}$ Patimah Sari siregar $^{5}$

1,2,3,4 Mahasiswa Fakultas Keperawatan dan Kebidanan UNPRI. Email :

wiwik.dalimunthe97@gmail.com

${ }^{5}$ Dosen Fakultas Keperawatan dan Kebidanan UNPRI. Email : patimahsari818@gmail.com 
artikan bahwa adanya pengaruh mobilisasi dini terhadap suara bising usus pada pasien pasca bedah.

\section{KESIMPULAN}

Penelitian ini dilakukan di RSU Royal Prima Medan pada pasien post op appendectomy. Sebelum dilakukan teknik mobilisasi dini pada pasien post appendectomy, suara perisaltik tidak terdengar jelas dan setelah dilakukan tehnik mobilisasi dini, suara perisaltik terdengar jelas. Mobilisasi dini berpengaruh terhadap suara peristatik pada pasien post appendectomy dapat dilihat dari hasil Sig. (2-tailed) $0,000<0,05$.

\section{Saran}

Bagi Peneliti Selanjutnya

Dapat sebagai gambaran bagi peneliti selanjutnya dengan mengambil kasus penyakit yang sama tetapi menggunakan metode yang berbeda

\section{Bagi Responden}

Dapat dijadikan sebagai edukasi dan informasi bagi keluarga dan masyarakat, serta menambah kepatuhan dalam menjaga pola hidup sehat

\section{Bagi peneliti selanjutnya}

Penelitian dapat dijadikan gambaran untuk meneliti lebih luas lgi bagaimana manfaat mobilisasi dini terhadap suara peristaltik usus pada pasien post op appdendectomy

\section{DAFTAR PUSTAKA}

$\begin{array}{rrr}\text { Anelia, Nicky. } & \text { 2013. Efektifitas } \\ \text { Latihan } & \text { Kekutan Otot } \\ \text { Terhadap } & \text { Kemampuan } \\ \text { Mobilisasi } & \text { Klien Dengan }\end{array}$

Fraktur Di Ruang Rawat Anggrek Tengah Kanan RSU Persahabatan [ Karya Ilmiah Akhir Ners]. Depok (ID) : Fakultas IImu Keperawatan Universitas Indonesia.

Anggraini, Meiga. 2015. Pengaruh Mobilsasi Dini terhadap Keberhasilan Penyembuhan Luka pada Pasien Pasca Operasi di RS PKU Muhammadiyah Yogyakarta.

Arikunto, S. (2016). Prosedur Penelitian Suatu Pendekatan Praktik. Jakarta: Rineka Cipta.

Armiyati, dkk. 2018. Pengaruh Mengunyah Permen Karet Terhadap Peristaltik Usus Pasien Post Appendectomy. Jurnal Penelitian Keperawatan Medik. Vol 1 No $1: 19$.

Basri, A. H., \& Nanuk. (2018). Pengaruh Mengunyah Permen Karet Terhadap Peristaltik Usus Post Appendiktomi. Journal of Ners Community, 9(1),43-53

Burhan. 2016. Metode Penelitian Kuantatif, Ed.2, Jakarta: Kencana

Daru Eko,dkk.(2016). Pengaruh Mobilsasi Dini ROM Pasif Terhadap Pemulihan Peristaltik Usus Pada Pasien Paska Pembedahan dengan Anestesi Umum Di SMC RS Telogorejo. Jurnal IImu Keperawatan dan Kebidanan .Vol 2. No.5.

\footnotetext{
Nora Santika ${ }^{1}$, Wiwik Listari ${ }^{2}$, Nur Ainun ${ }^{3}$, Lela Rahmadani ${ }^{4}$,Patimah Sari siregar ${ }^{5}$ 1,2,3,4 Mahasiswa Fakultas Keperawatan dan Kebidanan UNPRI. Email : wiwik.dalimunthe97@gmail.com

${ }^{5}$ Dosen Fakultas Keperawatan dan Kebidanan UNPRI. Email : patimahsari818@gmail.com
} 
Ditya, W., Asril, Z \& Afriwardi. (2016). Hubungan Mobilisasi Dini Dengan Proses Penyembuhan Luka Pada Pasien Pasca Laparatomi di Bangsal Bedah Pria dan wanita RSUP Dr M Djamil Padang. Jurnal Kesehatan Andalas , 5(3)724-729

Hidayat, A. Azis Almul. 2015. Kebutuhan Dasar Manusia. Jakarta: EGC.

Kozier, B. (2016). Buku Ajar Fundamental Keperawatan Konsep \& Praktik Edisi \& Vol.2. Jakarta:EGC

Manuaba, IBG, Manuaba, Chandrawati \& Manuaba, Fajar (2007). Pengantar Kuliah Obstetri. Jakarta:EGC

Mubarak, W. I Indrawati, LilisSusanto, J. 2015. Buku Ajar Ilmu Keperawatan Dasar. Jakarta : SalembaMedika.

Ningrum, D. S., Katuuk, M. E., \& Gresty, N. M. M. (2018). Pengaruh mobilisasi Dini Terhadap Peristaltik Usus Pada Pasien Psca Laparatomi Di RSU GMIM Pancaran Kasih Manado. E-journal Keperawatan, 6(1), 1-7

Notoatmodjo, Prof. $\mathrm{Dr}$ Soekidjo. 2012. Metodologi Penelitian Kesehatan. Jakarta: Rineka Cipta

Potter, P., Perry, A. (2015). Fundamental Keperawatan Konsep \& Praktik Edisi 7 Vol.2. Jakarta:EGC
Sari, P.N.(2013). Pengaruh Mobilisasi Dini Terhadap Peningkatan Peristaltic Usus Pada Pasien Post Operasi Di RSU Dr. Wahidin Sudiro Husodo Mojokerto.

Http: / /Ejurnal.Stikesmajapa hitmojokerto.Ac.Id/Index.Ph $\mathrm{p} / \mathrm{MM} /$ Article/View/37.

Sembiring, Oktavia Azima. 2018. Prevalensi Peritonitis Pada Pasien Apendisitis Di RSUD Haji Adam Malik Medan. [Skripsi]. Medan (ID):Fakultas Kedokteran Sumatra Utara.

Sriharyanti, E. D., Ismonah., Arif, S. (2016) Pengaruh Mobilisasi Dini ROM Pasif Terhadap Pemulihan Peristaltic Usus Pada Pasien Pasca Pembedahan Dengan Anestesi Umum Di SMC RS Telogorejo. Http: / /Ejournal.Stikestelogor ejo.Ac.Id/Index.Php/Jik/Arti cle/View/367.

Syaifuddin, 2012. Fisiologi Tubuh Manusia. Jakarta: Salemba Medika.

\footnotetext{
Nora Santika ${ }^{1}$, Wiwik Listari ${ }^{2}$, Nur Ainun ${ }^{3}$, Lela Rahmadani ${ }^{4}$ Patimah Sari siregar $^{5}$ 1,2,3,4 Mahasiswa Fakultas Keperawatan dan Kebidanan UNPRI. Email : wiwik.dalimunthe97@gmail.com

${ }^{5}$ Dosen Fakultas Keperawatan dan Kebidanan UNPRI. Email : patimahsari818@gmail.com
} 